\title{
The Evaluation of Intrathecal Morphine for Post Operative Analgesia in Vaginal Hysterectomy
}

\author{
Darshan Ashvin Trivedi ${ }^{1}$, Harsha Patel ${ }^{1}$, Prachi Kunal Shah ${ }^{1}$
}

${ }^{1}$ MD Anaesthesiology. Govt. Medical College, Surat, Gujarat, India.

Institute at which research was conducted: Govt. Medical College, Surat, Gujarat, India.

University Affiliation of Thesis: Veer Narmad South Gujarat University, Surat.

Year of Acceptance: 2013

\section{Address of Correspondence}

Dr. Darshan A Trivedi Dept of Anaesthsiology, Govt. Medical college and New Civil Hospital, Majura Gate, Surat. 395001, Gujarat, India. E mail: trivedida@gmail.com

Abstract: Background: A prospective randomized study was undertaken to evaluate the efficacy of intrathecal morphine along with bupivacaine for post-operative analgesia in patients undergoing vaginal hysterectomy.

Materials and methods: The study was conducted on 80 female patients in the age group of 18 to 60 years, belonging to ASA grade I to III scheduled for vaginal hysterectomy. Patients were randomly divided in to two equal groups,one receiving morphine(group M) and other normal saline(group B). Baseline pulse rate, blood pressure, respiratory rate, Visual analogue scale and sedation score were recorded \& monitored at regular intervals.

Result: Respiratory rate \& Oxygen saturation remained normal in both groups. Fall in pulse rate was more in group M Blood pressure was lower in group $\mathrm{M}$ as compared to group B. Higher sedation score in group M, sensory and motor blockade achieved was faster in group $\mathrm{M}$ with improved VAS score and less serious side effects.

Conclusion: We thus conclude that intrathecal administration of $0.1 \mathrm{mg}$ preservative free morphine along with $0.5 \%$ bupivacaine $(17.5 \mathrm{mg})$ significantly prolongs the duration of post-operative analgesia up to 14 hours. It also reduces postoperative analgesic requirement in first 24 hours.

Keywords: Intrathecal morphine, spinal anesthesia, vaginal hysterectomy.

\section{THESIS SUMMARY}

\section{Introduction:}

Intrathecal morphine has been one method of providing postoperative pain relief for more than two decades. Morphine, which is more hydrophilic than other opioids, has a longer residence time in the CSF and therefore may reach rostral sites over a longer period than other opioids. The basis of this is related to the location of opioids receptors in the substantia gelatinosa of the spinal cord. Opioid receptor activation inhibits the presynaptic release and postsynaptic response to excitatory neurotransmitters from nociceptive neurons. Transmission of pain impulses are interrupted at the spinal cord level. Consequently, there is a potential of achieving adequate and longlasting analgesia with an intrathecal injection of morphine. However, the downside of this hydrophilic character is an increased risk of adverse effects, especially delayed respiratory depression. By providing good analgesia for an extended period, intrathecal morphine considerably reduces the systemic opioids requirement. The side effects associated with intrathecal morphine are pruritus, sedation, nausea, vomiting and delayed respiratory depression which warrants close monitoring of the patients for the first 24hours. Some of the side effects can be reversed with
naloxone.This study was undertaken to evaluate the efficacy of intrathecal morphine added to bupivacaine spinal anaesthesia in patients undergoing vaginal hysterectomy with regard to onset and duration of anaesthesia, haemodynamic effects, postoperative analgesia, sedation, and

\begin{tabular}{|c|l|}
\hline Group M & $\begin{array}{l}\text { Inj. Hyperbaric Bupivacaine (0.5\%) } 17.5 \mathrm{mg} \\
(3.5 \mathrm{ml})+\text { Preservative free Inj. Morphine } \\
\text { Sulphate 100 } \mathrm{gg}(0.1 \mathrm{ml}) \text { intrathecaly to a } \\
\text { total volume of 3.6ml }\end{array}$ \\
\hline Group B & $\begin{array}{l}\text { Inj. Hyperbaric Bupivacaine }(0.5 \%) 17.5 \mathrm{mg} \\
(3.5 \mathrm{ml})+\text { Inj. Normal saline }(0.9 \%) 0.1 \mathrm{ml} \\
\text { intrathecaly to a total volume of } 3.6 \mathrm{ml}\end{array}$ \\
\hline
\end{tabular}


occurrence of any side effects.

\section{Materials and methods:}

A prospective randomized study The study was conducted on 80 female patients in the age group of 18 to 60 years, belonging to ASA grade I to III scheduled for vaginal hysterectomy Patients were randomly divided in to two equal groups.

They received intrathecal drugs as follows.

In pre anaesthesia room, pulse rate, blood pressure and respiratory rate were noted \& patients were preloaded with 1litre of crystalloids and premedicated with inj glycopyrrolate $0.004 \mathrm{mg} / \mathrm{kg}$ and inj odansatron $4 \mathrm{mg}$ intravenously.

In operation theatre, lumbar puncture was performed under strict aseptic and antiseptic precaution in the lateral decubitus position at the level of L3-4 or L2-3 inter space using $23 \mathrm{G}$ or $25 \mathrm{G}$ number spinal needle. After ensuring free flow of CSF, study drug was injected. The time of intrathecal injection was noted and immediately after it patients were turned to supine. Baseline pulse rate, blood pressure, respiratory rate and sedation score(ramsay scale) were recorded \& monitored every 5 minutes up to 30 minutes, at 45 minutes, 60 minute, 90 minute, 120 minute, 150 minute, $3 \mathrm{~h}, 4 \mathrm{~h}, 5 \mathrm{~h}, 6 \mathrm{~h}, 9 \mathrm{~h}, 12 \mathrm{~h}$ and at 24 hour. Visual analogue scale for pain was recorded at $1 \mathrm{~h}, 2 \mathrm{~h}$, $3 \mathrm{~h}, 4 \mathrm{~h}, 5 \mathrm{~h}, 6 \mathrm{~h}, 9 \mathrm{~h}, 12 \mathrm{~h}$ and at $24 \mathrm{hrs}$. Sensory blockade was assessed after injection of the drug to complete ablation of pinprick test. Motor blockade was assessed by bromage scale. Post-operatively rescue analgesia was supplemented with inj. diclofenac sodium 1.5 $\mathrm{mg} / \mathrm{kg}$ intramuscularly when VAS score $>3$. Patients were observed for side effects like hypotension, bradycardia, respiratory depression, nausea, vomiting, urinary retention and itching.

\section{Results:}

The age and weight of the patients and duration of surgery were comparable in both the groups ( $p>0.05)$.A fall in pulse rate was more in group $\mathrm{M}$ as compared to group B but it was statistically significant $(\mathrm{p}<0.05)$ only during 120 minutes to 5 hours after intrathecal injection of the drug. The lowest values of pulse were seen between 90-120 minutes in group $\mathrm{M}$ and B.Blood pressure was lower in group $\mathrm{M}$ as compared to group B during whole study period but did not reach statistical significance $(\mathrm{p}>0.05)$. The lowest values of blood pressure were seen between 90-120 minutes in group $\mathrm{M}$ and B.Respiratory rate \& Oxygen saturation remained normal in both groups at all time intervals during surgery and for $24 \mathrm{hrs}$ postoperatively. $(\mathrm{p}>0.05)$. Higher sedation score in group $\mathrm{M}$ as compared to group B from 25 minutes after intrathecal injection of the drug up to 6 hours $(\mathrm{p}<0.001)$. During this period, the patients were easily aroused but asleep when not disturbed. In the rest of period, the sedation score was comparable with group B ( $p>0.05)$. The mean time of sensory blockade from intrathecal injection to onset of sensory analgesia at L1 level was $1.169 \pm 0.731$ minutes in group $\mathrm{M}$ and $1.806 \pm 0.952$ minutes in group $\mathrm{B}(\mathrm{p}<0.05)$. In both groups highest sensory level achieved was T4-T8. The mean time to achieve highest sensory level was $5.950 \pm 2.490$ minutes in group $\mathrm{M}$ and $6.400 \pm 3.078$ minutes in group $\mathrm{B}(\mathrm{p}>0.05)$. The mean time of motor blockage from intrathecal injection to onset of grade 3 motor block was 5.0 \pm 1.536 minutes in group $\mathrm{M}$ and $5.400 \pm 1.905$ minutes in group B ( $>$ > 0.05). The mean duration of motor block was 207.750 \pm 23.176 minutes in group $\mathrm{M}$ and $214 \pm 25.201$ minutes in Group B
$(\mathrm{p}>0.05)$.VAS score was higher in group B as compared to group $\mathrm{M}$ at all time intervals except at 12 th hours $(\mathrm{p}<0.001)$, as by that time all patients in group $\mathrm{B}$ had already received rescue analgesia. In group M, 8 patients (20\%) did not require analgesic on the day of surgery. The average duration of analgesia was $13.825 \pm 4.206$ hours in group $\mathrm{M}$ and $4.762 \pm 0.679$ hours in group $\mathrm{B}(\mathrm{p}<0.001)$. Total number of rescue analgesic doses required were significantly less in group M (1.225 \pm 0.480 injections) as compared to group B (2.65 \pm 0.580 injections $)(\mathrm{p}<0.001)$.Intra-operatively, bradycardia occurred in $17.5 \%$ of patients in group $\mathrm{M}$ and $2.5 \%$ of patients in Group B, it was treated with inj atropine sulphate $0.6 \mathrm{mg}$ intravenously. No patient developed hypotension which required treatment. $37.5 \%$ patients in group $\mathrm{M}$ and $15 \%$ patients in group B developed nausea and vomiting $(\mathrm{p}<0.05) .37 .5 \%$ patients in group $\mathrm{M}$ developed pruritus while no patients in group B developed pruritus $(\mathrm{p}<0.001)$. No patients in any group developed respiratory depression.

\section{Conclusion:}

We thus conclude that intrathecal administration of $0.1 \mathrm{mg}$ preservative free morphine along with $0.5 \%$ bupivacaine $(17.5 \mathrm{mg})$ significantly prolongs the duration of post-operative analgesia up to 14 hours. It also reduces post-operative analgesic requirement in first 24 hours. It leaves the patient calm, comfortable, minimally sedated though easily arousable during intraoperative and immediate post operative period without any serious adverse effects except vomiting and pruritus which is easily treatable.

\section{Key Words:}

Intrathecal morphine, spinal anesthesia, vaginal hysterectomy.

\section{Bibliography}

1.Almeida RA, Lauretti GR, Mattos AL. Antinociceptive Effect of Low-Dose Intrathecal Neostigmine Combined with Intrathecal Morphine following Gynecologic Surgery. Anesthesiology 2003, 98(2): 495-498.

2.Andrieu G, Roth B, Ousmane L, Castaner M, Petillot P, Vallet B, et al : The Efficacy of Intrathecal Morphine With or Without Clonidine for Postoperative Analgesia After Radical Prostatectomy. Anesth Analg 2009; 108(6): 1954-1957.

3.Chaurasia B.D. Human anatomy, 4th edition, 2004; vol.3: 85-88.

4.Collins VJ. Principles of anaesthesiology, general and regional anaesthesia, 3 rd edition: 1993, Vol2: 1317-1346, 1571-1605, 1232-1316.

5.Gehling $M$, Tryba M. Intrathecal morphine in orthopaedic surgery patients, Optimised dose in patients receiving dipyrone. Anaesthesist, 2008; 57(4):347-354.

6.Gwirtz KH, Young JV, Byers RS, Alley C, Levin K, Walker SG. The Safety and Efficacy of Intrathecal Opioid Analgesia for Acute Postoperative Pain: Seven Years' Experience with 5969 Surgical Patients at Indiana University Hospital. Anesth Analg, 1999; 88: 599 - 604.

7.Hasset P, Ansari B, Gnanamoorthy P, Kinirons B, Laffey J G. Determination of the efficacy and side-effect profile of lower doses of intrathecal morphine in patients undergoing total knee arthroplasty. BMC Anesthesiol, 2008; 24: 8:5.

8. Hein A, Rösblad P, Haegerstrand CG, Schedvins K, Jakobsson J, Dahlgren GA. Low dose intrathecal morphine effects on post-hysterectomy pain: a randomized placebocontrolled study. Acta Anaesthesiol Scand 2012; 56: 102-109.

9.Jiang CJ, Liu CC, Wu TJ, Sun WZ, Lin SY, Huang FY et al: Mini-dose intrathecal morphine for post-cesarean section analgesia. Ma zui xue za zhi=Anaesthesiologica Sinica, 1992; 29(4): 683-689.

10.Kamath S S, Hosagoudar P, Ambareesha : Comparison of Efficacy of Intrathecal Morphine $100 \mu \mathrm{g}$ and $200 \mu \mathrm{g}$ for Postoperative Pain Relief in Patients Undergoing Lower Abdominal and Lower Limb Surgeries, J Anaesth Clin Pharmacol, 2009; 25(1): 63-65. 
11. Kara I, Apiliogullari S, Oc B, Celik JB, Duman A, Celik C, et al: The Effects of Intrathecal Morphine on Patient-controlled Analgesia, Morphine Consumption, Postoperative Pain and Satisfaction Scores in Patients Undergoing Gynaecological Oncological Surgery. Journal of International Medical Research, 2012; 40: 666-672.

12. Karaman S, Kocabas S, Uyar M, et al: Intrathecal morphine: effects on perioperative hemodynamics, postoperative analgesia and stress response for total abdominal hysterectomy. Adv Ther 2006; 23: 295 - 306.

13. Kirson LE, Goldman JM, Slover RB. Low-dose intrathecal morphine for postoperative pain control in patients undergoing transurethral resection of the prostate. Anesthesiology, 1989; 71(2): 192-195.

14.Kumar A, Srivastava U, Sacna S, Gupta A, Goyal V : Comparison of Intrathecal Morphine and Pethidine for Post Caesarean Analgesia and Side Effects, J Anesth Clin Pharmacology, 2007; 23(l): 35-39.

15. Mahajan B K. Methods in Biostatistics: 6th edition 1997.

16. Marion EK, Hansen K, Tegerstedt G E, Svensen C H, Andrijauskas A, Drobin D. Spinal blocks with and without morphine in women undergoing hysterectomies - a randomized study. Sri Lankan Journal of Anaesthesiology 2010; 18(1): 23-28.

17. Miller RD. Chronic pain, Local anaesthetics, Spinal anaesthesia: Anaesthesia Textbook, 2006; 6th edition: 2729-2762, 573-603, 1661-1670.

18.Morgan Edward G, Mikhail Jr. Maged S, Murry Michael J. Pain Pathway: Clinical Anaesthesiology; 4thedition: 362-367.

19.Nakamura T, Hase K, Fujihara T, Ogawa T, Urabe A, Asari E, Yoshioka H. Combined intrathecal morphine and bupivacaine for elective post-caesarean pain. Masui, the Japanese journal of anesthesiology, 2009; 58(4):416-421.

20.Oberhofer D, Sakic K, Nesek-adam V, Smiljanic A, Grizelj-stojcic E, Vukelic M, et al: Low dose spinal morphine and intravenous diclofenac for postoperative analgesia after total hip and knee arthroplasty. Periodicum Biologorum 2011;113(2): 191-196.
21.Palashevska L, Jovcevski S, Popovska S, Popovska R, Curlinov K. Low dose intrathecal morphine for postoperative analgesia after vaginal hysterectomy: Comparative clinical examination of two different small doses. European Journal of Anaesthesiology, 2011; 28: $124-125$.

22.Rajgopal M.R. Pain - basic consideration. Indian journal of anaesthesia, 2006; 50 (5): 331-334.

23. Salmah G S, Choy Y C. Comparison of Morphine with Fentanyl Added to Intrathecal 0.5\% Hyperbaric Bupivacaine for Analgesia After Caesarean Section. Med J Malaysia, 2009; 64(1): $71-74$.

24.Sfeir S, Mansour N. Post operative analgesia with intrathecal morphine. Middle East J Anesthesiol, 2005; 18(1): 133-139.

25.Sarma VJ, Boström UV. Intrathecal morphine for the relief of post-hysterectomy paina double-blind, dose-response study. Acta Anaesthesiol Scand 1993; 37:223-7.

26.Satoh O, Hatakeyama Y, Miyazawa F, Tsumura T, Miyabe M, Namiki A. Intrathecal morphine for postoperative pain relief after transvaginal hysterectomy. Masui, the Japanese journal of anesthesiology, 1992; 41(9): 1517-1519.

27.Slappendel R, Weber EW, Dirksen R, Gielen MJ, van Limbeek J. Optimization of the dose of intrathecal morphine in total hip surgery: a dose-finding study. Anesth Analg 1999, 88(4): 822-826.

28.Stoelting RK, Hillier SC: Pharmacology and physiology in anaesthetic practice, 4th edition: 179-207, 83-122.

29.Thripathi K. D: Essentials of medical Pharmacology; 5thedition: 2004.

30. Wylie and Churchill Davidson's: A practice of Anaesthesia; 7thedition.

31.Yang T, Breen T W, Archer D, Fick G. Comparison of $0.25 \mathrm{mg}$ and $0.1 \mathrm{mg}$ intrathecal morphine for analgesia after Cesarean section. Can J Anesth, 1999; 46(9): 856-860.
Conflict of Interest: Nil Source of Support: None
Full Thesis and Master Chart available on www.journalmedicalthesis.com

\section{How to Cite this Article:}

Trivedi DA, Patel H, Shah PK. The Evaluation of Intrathecal Morphine for Post-Operative Analgesia. Journal Medical Thesis 2013 JulySep; 1(1):14-16 